\title{
An epizootic in farmed, market-size rainbow trout in Spain caused by a strain of Carnobacterium piscicola of unusual virulence
}

\author{
A. E. Toranzo ${ }^{1}$, J. L. Romalde ${ }^{1}$, S. Nuñez ${ }^{1}$, A. Figueras' ${ }^{2}$, J. L. Barja ${ }^{1}$ \\ ${ }^{1}$ Departamento de Microbiología y Parasitología, Facultad de Biología, Universidad de Santiago de Compostela, \\ E-15706 Santiago de Compostela, Spain \\ ${ }^{2}$ Instituto de Investigaciones Marinas, CSIC, Eduardo Cabello 6, E-36208 Vigo, Spain
}

\begin{abstract}
We report here the first description in Spain of a Camobacterium strain causing important mortalities in market-size rainbow trout Oncorhynchus mykiss. Relevant clinical signs in affected fish were a pronounced bilateral exophthalmia with periocular hemorrhages, accumulation of ascitic fluid. and hemorrhages in the liver, swimbladder, muscle, and intestine. Taxonomic studies conducted in comparison with reference strains indicated that the present isolate (PT-31) was Carnobacterium piscicola. Agglutination assays demonstrated that this isolate was not serologically related to the reference strains. In addition, an analysis of the surface proteins revealed that different patterns occurred among the $C$. piscicola isolates. Although the immunoblotting assays supported the antigenic heterogeneity within this species, all strains did share 2 major antigenic proteins of 30 and $57 \mathrm{kDa}$. Interestingly, this immunoreactive $57 \mathrm{kDa}$ protein is also produced by Renibacterium salmoninarum and Corynebacterium aquaticum. Regardless of the challenge method (injection or water-borne), isolate PT-31 proved to be highly pathogenic for rainbow trout $\left(\mathrm{LD}_{50}<5-6 \times 10^{4}\right.$ cells), and the moribund fish displayed the external and internal signs observed in the natural disease. The inoculated strain could be recovered from various organs of both dead and surviving fish. The extracellular products (ECP) of strain PT-31 contained exotoxins lethal for rainbow trout ( $\left(\mathrm{D}_{50}=4.5 \mu \mathrm{g}\right.$ protein $\mathrm{g}^{-1}$ fish). However, the toxic ECP lacked enzymatic, cytotoxic, and hemolytic activities when tested in vitro. Histopathological examination of naturally and experimentally infected trout showed extensive and/or intensive lesions in most organs. The most marked tissue damage (acute hemorrhages and necrosis) was observed in eyes, kidney, liver, spleen, pancreas, and muscle. These findings should alert fish farmers to the existence of $C$ piscicola strains with a pathogenic capability higher than that previously recorded.
\end{abstract}

KEY WORDS: Carnobacterium piscicola $\cdot$ Rainbow trout - Serology · Taxonomy · Virulence

\section{INTRODUCTION}

Bacteria with characteristics resembling species of Lactobacillus or Carnobacterium have been isolated from seemingly healthy fish in routine microbiological surveys as well as from diseased fish (Table 1). In the majority of the disease cases, lactic acid bacilli have been recovered from chronically infected salmonids cultured in North America and mortality levels have been low. However, reports do indicate that the bacilli can also infect other commercially important species of fish such us striped bass, channel catfish, and carp (Michel et al. 1986, Baya et al. 1991).
The lactic acid bacteria form a biochemically and genetically heterogeneous group which have undergone substantial taxonomic revision. Although Lactobacillus piscicola (Hiu et al. 1984) was included in the genus Carnobacterium (Collins et al. 1987), some atypical lactobacilli isolated from salmonid fish were classified as new species: Vagococcus salmoninarum (Wallbanks et al. 1990) and Lactococcus piscium (Williams et al. 1990), on the basis of an analysis of their $16 \mathrm{~S}$ rRNA sequences. However, the significance of these 2 last-named species for aquaculture remains to be determined.

With rare exceptions (Baya et al. 1991, Toranzo et al. 1993), attempts to experimentally reproduce disease or 
Table 1. Reports of lactic acid bacilli isolated from apparently healthy and diseased fish

\begin{tabular}{|c|c|c|c|}
\hline Fish group & Country of isolation & Bacteria described & Source \\
\hline \multicolumn{4}{|l|}{ Healthy fish } \\
\hline Saimonids & Canada & Lactobacillus sp. & Evelyn \& McDermott (1961) \\
\hline Salmonids & CIS & Lactobacillus sp. & Kvasnikov et al. (1977) \\
\hline Salmonids & Denmark & Lactobacillus sp. & Knöchel (1981) \\
\hline Salmonids & Australia & Lactobacillus piscicola & Humphrey et al. (1987) \\
\hline Brown bullhead & USA & Carnobacterium piscicola & Baya et al. (1991) \\
\hline Salmonids & USA & Carnobacterium piscicola & Starliper et al. (1992) \\
\hline Salmonids & Iceland & $\begin{array}{l}\text { Carnobacterium piscicola } \\
\text { and Lactobacillus sp. }\end{array}$ & Stoffels et al. (1992) \\
\hline \multicolumn{4}{|l|}{ Diseased fish } \\
\hline Salmonids & USA & Lactobacillus sp. & Rucker et al. (1953) \\
\hline Salmonids & USA & Lactobacjllus sp. & Ross \& Toth (1974) \\
\hline Salmonids & Canada & Lactobacillus sp. & Cone (1982) \\
\hline Salmonids & USA & Lactobacillus piscicola & Hiu et al. (1984) \\
\hline Salmonids & USA & Lactobacillus piscicola & Herman et al. (1985) \\
\hline Salmonids & Australia & Lactobacillus piscicola & Humphrey et al. (1987) \\
\hline $\begin{array}{l}\text { Salmonids } \\
\text { and carp }\end{array}$ & France, Belgium & Lactobacillus piscicola & Michel et al. (1986) \\
\hline Salmonids & USA & Vagococcus salmoninarum & Wallbanks et al. (1990) \\
\hline Salmonids & USA & Lactococcus piscium & Williams et al. (1990) \\
\hline $\begin{array}{l}\text { Striped bass and } \\
\text { channel catfish }\end{array}$ & USA & Carnobacterium piscicola & Baya et al. (1991) \\
\hline Salmonids & USA & $\begin{array}{l}\text { Carnobacterium piscicola } \\
\text { and Lactobacillus sp. }\end{array}$ & Starliper et al. (1992) \\
\hline Salmonids & Spain & Carnobacterium piscicola & Present study \\
\hline
\end{tabular}

mortality in fish with Lactobacillus or Carnobacterium strains have not been very successful (Ross \& Toth 1974, Herman et al. 1985, Michel et al. 1986, Starliper et al. 1992). In addition, most of the isolations have been made from adult fish which had experienced stress, such as that associated with handling and spawning. These facts indicated that these microorganisms are generally opportunistic pathogens and that they possess low virulence.

To date, there have only been a few reports of isolations of Carnobacterium from diseased fish in Europe (Michel et al. 1986) (Table 1). We therefore report on a recent case of Carnobacterium piscicola from Spain. The case was unusual because it represented an infection wth a highly virulent strain of $C$. piscicola and because it was associated with large and acute losses in market-size rainbow trout Oncorhynchus mykiss. Consequently, an extensive phenotypic and serological characterization of this microorganism was conducted. In addition, its pathobiological activities in vitro and in vitro were also evaluated.

\section{MATERIALS AND METHODS}

Description of the disease and microbiological examination. In July 1992, a disease outbreak causing high mortalities occurred in market-size (average weight $250 \mathrm{~g}$ ) rainbow trout reared in a freshwater farm located in NW Spain. The fish were stocked in concrete tanks at a density of $20 \mathrm{~kg} \mathrm{~m}^{-2}$ and were being fed a commercial trout food. The epizootic was associated with a sudden rise in the water temperature from 17 to $22^{\circ} \mathrm{C}$ ). An initial treatment with oxolinic acid failed to control the disease. Therefore, therapy was changed to chloramphenicol which proved to be only moderately useful for controlling the epizootic. Fish losses over a 2 mo period amounted to about $25 \%$ of a total population of 600000 rainbow trout.

Diseased fish exhibited a pronounced bilateral exophthalmia with periocular hemorrhages, and a general darkening of the body surface (Fig. $1 a_{1}, a_{2}$ ). The most relevant internal clinical signs consisted of an accumulation of ascitic fluid in the peritoneal cavity and hemorrhages in the liver (showing strong

Fig. 1. External and internal clinical signs exhibited by rainbow trout Oncorhynchus mykiss suffering natural and experimental infections with Carnobacterium piscicolaPT-31 strain: $\left(a_{1}, a_{2}\right)$ pronounced bilateral exophthalmia with periocular hemorrhages, (b) general darkening of the body surface and marked petechiation in the liver, (c) hemorrhages in the musculature and swimbladder 

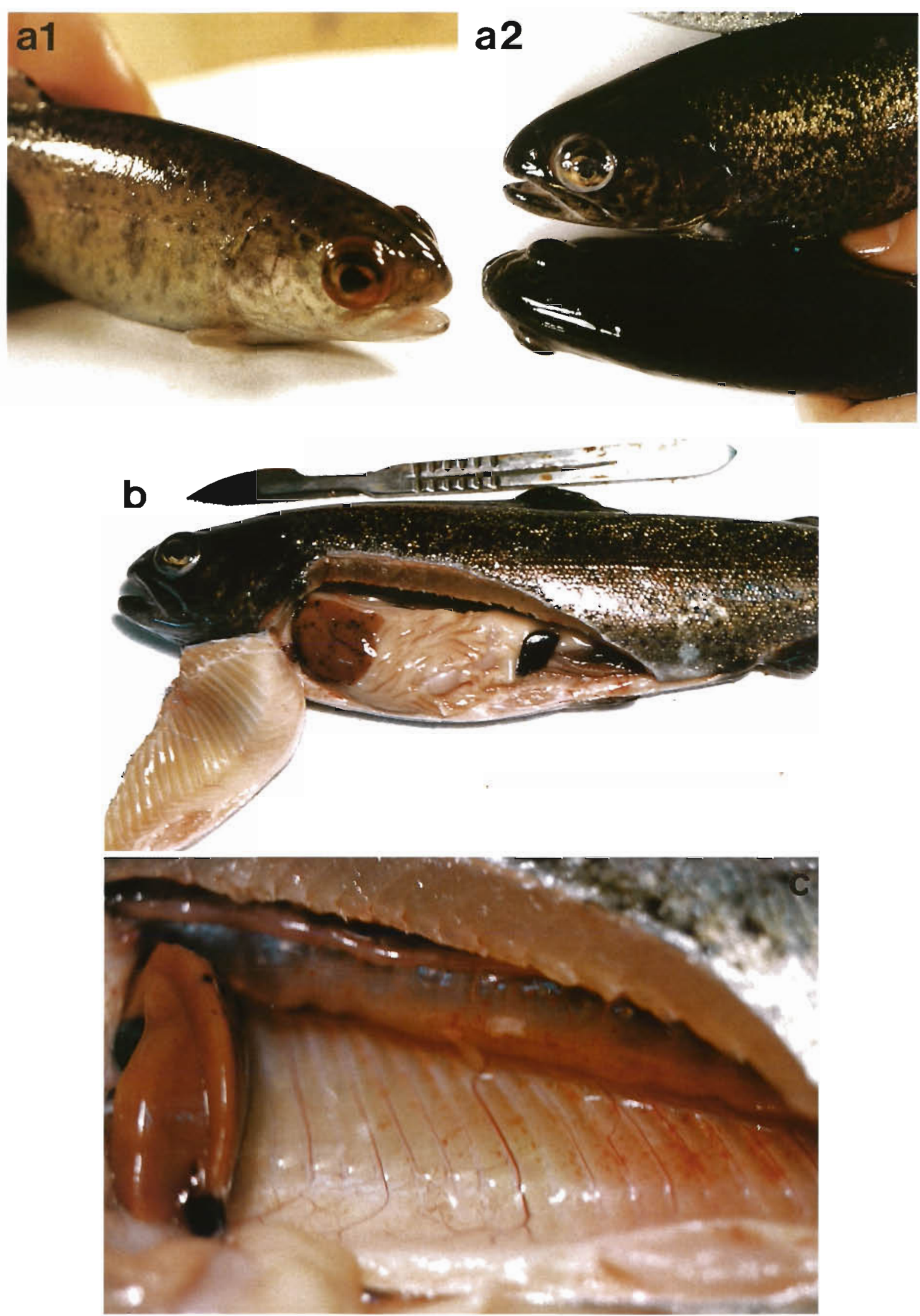
pethechiae), swimbladder, musculature, and intestines (Fig 1b, c). In some moribund trout, the kidney, liver, and spleen were also swollen.

For bacterial isolation, samples of kidney, liver, spleen, and eye tissues were streaked onto tryptic soy agar (TSA, Difco Laboratories, Detroit, MI, USA), brain heart infusion agar (BHIA, Difco), and blood agar (BioMerieux, Madrid, Spain). Samples were also inoculated into tryptic soy broth (TSB, Difco). Plates and broth tubes were incubated at $25^{\circ} \mathrm{C}$ for 48 to $72 \mathrm{~h}$.

Tests for the possible presence of a viral agent were also performed following standard virological procedures (Amos 1985)

Taxonomic and serological characterization. Pure cultures of the isolated colonies were subjected to morphological, biochemical, and physiological tests (Hiu et al. 1984, Kandler \& Weiss 1986, Collins et al. 1987). Acid production from carbohydrates was examined in phenol red broth base and purple broth base media, both supplemented with $0.5 \%$ yeast extract and the test sugar at a final concentration of $1 \%$. Enzymatic (proteases, phospholipase, lipase, and amylase) and hemolytic activities were determined in plates as previously described (Baya et al. 1991). The final reading of the results was conducted after $7 \mathrm{~d}$ incubation at $25^{\circ} \mathrm{C}$.

Drug sensitivity of the isolates was determined by the disc diffusion method on Mueller-Hinton agar (Oxoid, Ltd, Basingstoke, Hamsphire, UK) using the following chemotherapeutic agents $\left(\mu \mathrm{g}\right.$ disc $\left.^{-1}\right)$ : penicillin $G(10)$, ampicillin (10), tetracycline (30), oxytetracycline (30), chloramphenicol (30), erythromycin (15), streptomycin (10), oxolinic acid (2), flumequine (3), trimethoprim-sulfamethoxazole (23.75-1.25), nitrofurantoin (300), and furazolidone (100).

Because preliminary tests indicated that the present isolates (representative strain PT-31) were Grampositive organisms belonging to the genus Carnobacterium, the following reference strains of $C$. piscicola were included in the taxonomic and serological studies: type strain ATCC $35586\left(\mathrm{~B}-270^{\mathrm{T}}\right)$ isolated from diseased trout Salmo clarki in Oregon, USA (Hiu et al. 1984); strains HB 426 and HB 569L isolated in Maryland from epizootics in cultured striped bass Morone saxatilis and channel catfish Ictalurus punctatus, respectively: and strain RB 498 recovered from asymptomatic wild brown bullhead $I$. nebulosus in Chesapeake Bay (Baya et al. 1991).

Working cultures of all the strains were maintained in tubes of soft agar (casitone, $0.1 \%$; yeast extract, $0.3 \% ; \mathrm{NaCl}, 1 \%$ agar, $0.3 \%, \mathrm{pH} 7.2$ ) under mineral oil. For long-term preservation, cultures were frozen at $-70^{\circ} \mathrm{C}$ in TSB with $15 \%$ (v/v) glycerol.

The serological relationships among the Carnobacterium piscicola isolates were examined by slide agglutination tests as we previously described (Toranzo et al. 1987) using rabbit antisera raised against $C$. piscicola strains ATCC 35586 and HB 426. In addition, cross-quantitative agglutination tests were performed in microtiter plates using serial 2-fold dilutions of $25 \mu \mathrm{l}$ aliquots of the antisera. The agglutination titer was recorded as the reciprocal of the highest dilution of the antiserum which gave a positive reaction after overnight incubation with the antigen at $30^{\circ} \mathrm{C}$

Because, using the western blot technique, we have recently detected the presence of a common immunoreactive protein of about $57 \mathrm{kDa}$ among strains of Renibacterium salmoninarum, Corynebacterium aquaticum, and Carnobacterium piscicola (Bandin et al. 1993), agglutination assays were also conducted with antisera raised against the reference strain of R. salmoninarum ATCC 33209 (Lea 1-74 $4^{\mathrm{T}}$ ) and C. aquaticum RB 968 BA (Baya et al. 1992).

Virulence for fish. A representative strain from the present outbreak, Carnobacterium piscicola PT-31, and the reference strain of C. piscicola (ATCC 35586) were tested for pathogenicity in fingerling rainbow trout $(10 \mathrm{~g})$ maintained at $20 \pm 2{ }^{\circ} \mathrm{C}$ in freshwater aquaria with aeration. Two challenge methods were employed: intraperitoneal (i.p.) injection as previously described (Toranzo et al. 1983b), and water-borne exposure. After fish stocks were determined by culture to be free of $C$. piscicola or other bacterial species, infectivity trials were conducted using a range of bacterial doses ( 6 fish being used per dose). Mortalities were recorded daily over a $3 \mathrm{wk}$ period, and the degree of virulence $(50 \%$ lethal dose) was calculated by the Reed \& Müench method (1938). Control fish were exposed to $0.85 \%$ saline using the same challenge procedures.

From each moribund or dead fish, samples of kidney, liver, spleen, and brain were streaked directly onto BHIA plates in order to reisolate the challenge strain. In addition, kidney samples were taken from some of the dead fish as well as from the survivors. These kidney samples were homogenized, diluted in $0.85 \%$ saline, and plated on BHIA in order to determine the number of viable Carnobacterium piscicola cells present [colony-forming units (CFU) $\mathrm{g}^{-1}$ of tissue].

Histopathological studies. Samples of kidney, liver, spleen, pancreas, intestine, brain, and eye taken from moribund trout in both the natural and the experimental infections were fixed in $4 \%$ buffered formalin for $24 \mathrm{~h}$. The fixed samples were then embedded in paraffin and $5 \mu \mathrm{m}$ sections were prepared and stained with hematoxylin and eosin, and by the Gram and Giemsa methods.

Analysis of surface proteins and western blotting. Membrane proteins from all the Carnobacterium piscicola strains were prepared basically as described 
(Toranzo et al. 1983b). Briefly, bacterial cultures grown on TSB were centrifuged at $7000 \times \mathrm{g}$ for $10 \mathrm{~min}$ at $4^{\circ} \mathrm{C}$. The resulting cell pellets were resuspended in $3 \mathrm{ml}$ of $10 \mathrm{mM}$ Tris-HCl buffer $(\mathrm{pH} 8.0)$ with $0.3 \%$ added $\mathrm{NaCl}$, and the cells were disrupted by sonic treatment (Branson sonifier 250). After centrifugation at $10000 \times g$ for $1 \mathrm{~min}$, the supernatant fluids were transferred to other tubes and centrifuged again for $60 \mathrm{~min}$ at $20000 \times \mathrm{g}$ at $4^{\circ} \mathrm{C}$. The precipitates were suspended in distilled water, and these suspensions were frozen at $-30^{\circ} \mathrm{C}$ until used. Samples were electrophoresed in sodium dodecyl sulfate polyacrylamide gels (SDSPAGE) at constant current (20 mA) (Laemmli 1970). The proteins were stained with Coomassie brilliant blue R (Sigma Chemical Co., St. Louis, MO), and the molecular weights (MW) were determined by comparison with a mixture of MW markers (Bio-Rad). In the SDS-PAGE, membrane proteins of the Gram-positive fish pathogens Renibacterium salmoninarum ATCC 33209 and Corynebacterium aquaticum RB 968 BA were also included for comparative purposes.

After electrophoresis, proteins were electroblotted from the gel onto nitrocellulose (NC) membranes $(0.45 \mu \mathrm{m}$, Bio-Rad) using a modification of the method of Towbin et al. (1979). The membranes were then separately reacted with the antisera raised against Carnobacterium piscicola ATCC 35586, C. piscicola $\mathrm{HB} 426$, and Renibacterium salmoninarum ATCC 33209. NC membranes were incubated for $1 \mathrm{~h}$ with control or immune rabbit serum diluted 1:1000. After washing, membranes were incubated for $1 \mathrm{~h}$ with goat anti-rabbit IgG-alkaline phosphotase conjugate (BioRad) diluted 1:3000. Bands were visualized by incubating $\mathrm{NC}$ membranes in $0.1 \mathrm{M}$ carbonate buffer ( $\mathrm{pH}$ 9.8) containing tetrazolium blue $\left(0.3 \mathrm{mg} \mathrm{ml}^{-1}\right)$ and 5-bromo-4-chloro-3-indolyl phosphate $p$-toluidine salt (0.15 $\left.\mathrm{mg} \mathrm{ml}^{-1}\right)$.

In vivo and in vitro biological activities of extracellular products. The extracellular products (ECP) of the Spanish isolate C. piscicola PT-31 and the reference strain ATCC 35586 were obtained using the cellophane plate technique (Liu 1957) with slight modifications (Santos et al. 1992). The protein concentrations of the ECP samples were determined by the method of Bradford (1976) using bovine serum albumin as standard.

The total proteolytic activity present in the ECP was determined using a non-specific protease substrate (Azocoll, Sigma) following the manufacturer's instructions. One unit of protease activity produced an absorbance reading of 1.0 at $520 \mathrm{~nm}$ in $30 \mathrm{~min}$ at $37^{\circ} \mathrm{C}$. The production of caseinase, gelatinase, phospholipase, and lipase activities was quantified in plates by a radial diffusion method using a basal nutrient agar (BNA) (peptone, $4 \mathrm{~g} \mathrm{l}^{-1}$; yeast extract, $1 \mathrm{~g} \mathrm{l}^{-1}$; agar,
$15 \mathrm{~g} \mathrm{l}^{-1}$ ) containing $1 \%$ of the appropriate substrate: gelatin (Oxoid), sodium caseinate (Difco), egg yolk emulsion (Oxoid), or Tween 80 (Sigma) (Baya et al. 1992). Elastase activity was assayed on elastin medium (Santos et al. 1992). Ten $\mu$ l of each ECP was placed on the plates and incubated at $25^{\circ} \mathrm{C}$ for 24 to $72 \mathrm{~h}$ until final reading of the results (Baya et al. 1992). Hemolytic activity was measured in microtiter plates using a $2 \%$ suspension of sheep erythrocytes

The ECP preparations were assayed for cytotoxicity as previously described by Toranzo et al. (1983a), in the following fish cell lines: CHSE-214 (chinook salmon embryo), EPC (epithelioma papulosum cyprini), and RTM (rainbow trout muscle). Results were expressed as the minimal amount of ECP protein needed to produce detectable monolayer damage within a 2 d period.

The lethal effects of the Carnobacterium piscicola exotoxins were evaluated by i.p. and intramuscular (i.m.) inoculation of rainbow trout $(10 \mathrm{~g})$. Serial 2 -fold dilutions of ECP samples were tested $(0.1 \mathrm{ml}$ of each dilution of each ECP preparation per fish). Groups of 6 fish, maintained under the conditions described above for the virulence assays of live cells, were used per dose. The lethal dose $50 \%\left(\mathrm{LD}_{50}\right)$ was expressed as $\mu \mathrm{g}$ ECP protein $\mathrm{g}^{-1}$ body wt of fish.

\section{RESULTS AND DISCUSSION}

\section{Phenotypic characterization of the causative organism}

Microbiological examination of diseased trout revealed the presence of a single colony type from all of the tissues sampled. Colonies on TSA plates were white, round, convex, and less than $2 \mathrm{~mm}$ in diameter after 48 to $72 \mathrm{~h}$ incubation at $25^{\circ} \mathrm{C}$. The features of the isolates obtained from the sampled fish were consistent with those of the reference strains of Carnobacterium piscicola tested in parallel (Table 2). All were Gram-positive facultatively anaerobic, nonmotile, non-spore-forming straight rods that occurred singly or in short chains. They did not produce cytochrome oxidase, catalase, or indole, and did not reduce nitrate. All isolates were positive for the methyl red and Voges-Proskauer tests but negative for the citrate reaction; they failed to produce $\mathrm{H}_{2} \mathrm{~S}$ on triple sugar iron agar or gas from glucose or gluconate. In addition, all strains failed to grow on acetate agar and possessed the enzyme arginine dihydrolase, 2 important tests for differentiating Carnobacterium species from Lactobacillus, Vagococcus, and Lactococcus species (Collins et al. 1987. Wallbanks et al. 1990, Williams et al. 1990, Baya et al. 1991, Montel et al. 1991). 
Table 2. Biochemical and physiological characteristics of the Carnobacterium piscicola isolated in this study in comparison with those exhibited by other reference strains. + : positive $(+)$ : weak positive results ${ }_{i}-$ : negative $\alpha$ : $\alpha$-hemolytic activity; $\mathrm{R}$ : resistant; $\mathrm{S}$ : sensitive, I: intermediate

\begin{tabular}{|c|c|c|c|c|c|}
\hline \multirow[t]{3}{*}{ Test } & \multicolumn{5}{|c|}{ Camobacterum piscicola isolates } \\
\hline & \multicolumn{2}{|l|}{ Present study } & \multicolumn{2}{|c|}{ Reference strains } & \multirow[b]{2}{*}{ RB-498 } \\
\hline & PT -31 & ATCC 35586 & $\mathrm{HB}-426$ & HB-569L & \\
\hline Oxidase & - & - & - & - & - \\
\hline Catalase & - & - & - & - & - \\
\hline Methyl red & + & + & + & + & + \\
\hline Voges-Proskauer & + & + & + & + & + \\
\hline Indole production & - & - & - & - & - \\
\hline Nitrate reduction & - & - & - & - & - \\
\hline $\mathrm{H}_{2} \mathrm{~S}$ on TSI & - & - & - & - & - \\
\hline Citrate utilization & - & - & - & - & - \\
\hline Gas from glucose & - & - & - & - & - \\
\hline Gas from gluconate & - & - & - & - & - \\
\hline ONPG ( $\beta$-galactosidase) & + & + & + & + & + \\
\hline Arginine dihydrolase & + & + & + & + & + \\
\hline Lysine decarboxylase & - & - & - & - & - \\
\hline Ornithine decarboxylase & - & - & - & - & - \\
\hline \multicolumn{6}{|l|}{ Enzyme production: } \\
\hline Gelatinase & - & - & - & - & - \\
\hline Caseinase & - & $(+)$ & - & + & + \\
\hline Elastase & - & - & - & - & - \\
\hline Phospholipase & - & - & - & - & - \\
\hline Lipase & - & - & - & - & - \\
\hline Amylase & - & - & - & - & - \\
\hline Urease & - & - & - & - & - \\
\hline \multicolumn{6}{|l|}{ Hemolysis: } \\
\hline Sheep erythrocytes & $+\alpha$ & $1+1 \alpha$ & $(+) \alpha$ & $(+) \alpha$ & $1+1 \alpha$ \\
\hline Trout erythrocytes & $+\alpha$ & - & - & - & - \\
\hline \multicolumn{6}{|l|}{ Acid from: } \\
\hline D-mannitol & + & + & + & + & + \\
\hline Inulin & + & + & + & + & + \\
\hline D-sorbitol ${ }^{d}$ & $(+)$ & $(+)$ & $(+)$ & $(+)$ & $(+)$ \\
\hline Inositol & - & - & - & - & - \\
\hline Glycerol & - & $(+)$ & $(+)$ & - & - \\
\hline L-arabinose & - & - & + & - & + \\
\hline Sucrose & + & + & + & + & + \\
\hline Lactose & - & $1+1$ & - & $(+)$ & + \\
\hline D-ribose & + & + & + & + & + \\
\hline$D$-fructose & - & + & + & + & + \\
\hline Amygdalin & + & + & + & + & + \\
\hline Esculin & + & + & + & + & + \\
\hline \multicolumn{6}{|l|}{ Growth in: } \\
\hline $0 \% \mathrm{NaCl}$ & + & + & + & + & + \\
\hline $3 \% \mathrm{NaCl}$ & + & + & + & + & + \\
\hline $5 \% \mathrm{NaCl}$ & $(+)$ & + & + & + & + \\
\hline $8 \% \mathrm{NaCl}$ & - & - & - & - & - \\
\hline \multicolumn{6}{|l|}{ Growth at: } \\
\hline $4^{\circ} \mathrm{C}$ & - & + & + & + & + \\
\hline $15^{\circ} \mathrm{C}$ & + & + & + & + & + \\
\hline $37^{\circ} \mathrm{C}$ & + & + & + & + & + \\
\hline $42^{\circ} \mathrm{C}$ & - & - & - & - & - \\
\hline \multicolumn{6}{|c|}{ Growth on inhibitory media: } \\
\hline Acetate agar & - & - & - & - & - \\
\hline KF Streptococcus agar & + & + & + & + & + \\
\hline Mcconkey agar & - & - & - & - & - \\
\hline \multicolumn{6}{|c|}{ Resistance/sensitivity to $\left(\mu \mathrm{g} \mathrm{disc}{ }^{-1}\right)$ : } \\
\hline Penicillin G $(10\}$ & $\mathrm{s}$ & $\mathrm{R}$ & $\mathrm{s}$ & $\mathrm{s}$ & $\mathrm{s}$ \\
\hline Ampicillin (10) & $\mathrm{s}$ & $\mathrm{R}$ & $\mathrm{S}$ & $\mathrm{S}$ & $\mathrm{s}$ \\
\hline Tetracycline (30) & $\mathrm{R}$ & $\mathrm{S}$ & $\mathrm{s}$ & $\mathrm{R}$ & $\mathrm{R}$ \\
\hline Oxytetracycline (30) & $\mathrm{R}$ & $\mathrm{s}$ & $\mathrm{S}$ & $\mathrm{R}$ & $\mathrm{R}$ \\
\hline Chloramphenicol (30) & I & I & I & I & l \\
\hline Erythromycin (15) & $\mathrm{s}$ & $\mathrm{s}$ & $\mathrm{s}$ & 1 & $\mathrm{~s}$ \\
\hline Streptomycin (10) & $\mathrm{R}$ & $\mathrm{R}$ & $\mathrm{R}$ & $\mathrm{R}$ & $\mathrm{R}$ \\
\hline Oxolinc acid (2) & $\mathrm{R}$ & $\mathrm{R}$ & $\mathrm{R}$ & $\mathrm{R}$ & $\mathrm{R}$ \\
\hline Flumequine (3) & $\mathrm{R}$ & $\mathrm{R}$ & $\mathrm{R}$ & $\mathrm{R}$ & $\mathrm{R}$ \\
\hline $\begin{array}{l}\text { Trimethopnm (23.75)- } \\
\text { sulfamethoxazole (1.25) }\end{array}$ & $\mathrm{R}$ & $\mathrm{R}$ & s & R & R \\
\hline Nitrofurantoin (300) & $\mathrm{R}$ & $\mathrm{R}$ & $\mathrm{R}$ & $\mathrm{R}$ & $\mathrm{R}$ \\
\hline Furazolidone (100) & $\mathrm{R}$ & $\mathrm{R}$ & $\mathrm{R}$ & $\mathrm{R}$ & $\mathrm{R}$ \\
\hline
\end{tabular}

In their carbohydrate fermentation patterns, the isolates from the present epizootic (representative strain PT-31) differed from the reference strains mainly in their inability to ferment fructose (a substrate attacked by all of the reference strains) (Table 2). However, after a prolonged incubation period (more than $7 \mathrm{~d}$ ) this reaction became weakly positive. In all strains, variations were found in the fermentation of sorbitol and lactose depending on the basal medium utilized (phenol red broth or purple broth). This is important because the typical Carnobacterium piscicola strains are considered to be sorbitol-negative using the purple broth base medium (Hiu et al. 1984, Collins et al. 1987). In summary, the discrepancies among the results obtained by different authors in the sugar reactions (Cone 1982, Hiu et al. 1984, Herman et al. 1985, Michel et al. 1986, Baya et al. 1991, Starliper et al. 1992, Stoffels et al. 1992) can be attributed, as we previously reported (Baya et al. 1991), to variations in the basal medium used, time of reading, and methodology (conventional plate and tube tests versus commercial API-50 CHL system). However, in the present study, regardless of the basal medium utilized, all strains fermented mannitol and inulin, 2 characteristics useful for differentiating Carnobacterium from Vagococcus and Lactococcus and the only reliable criteria for separating the related Carnobacterium species, $C$. picicola and $C$. divergens (Collins et al. 1987, Wallbanks et al. 1990, Williams et al. 1990, Montel et al. 1991).

The physiological and enzymatic characteristics of our isolate PT-31 were similar to those exhibited by the reference strains, thus also supporting its assignation to the species Carnobacterium piscicola. None of the strains grew at $42^{\circ} \mathrm{C}$, and the salinity range for growth was from 0 to $5 \% \mathrm{NaCl}$. The strains failed to produce the enzymes gelatinase, elastase, phospholipase, lipase, amylase, and urease but exhibited an $\alpha$-hemolytic activity with sheep erythrocytes. Only our strain PT-31 displayed hemolytic activity against fish erythrocytes (Table 2). 
Table 3. Characteristics useful in differentiating Lactobacillus, Carnobacterium, Vagococcus, and Lactococcus species. Data compiled from information obtained in the present study and that reported by other authors (Collins et al. 1987. Wallbanks et al. 1990, Williams et al. 1990, Baya et al. 1991, Montel et al. 1991). V: variable reaction among the isolates

\begin{tabular}{|c|c|c|c|c|c|}
\hline Test & $\begin{array}{l}\text { Lactobacillus } \\
\text { spp. }\end{array}$ & $\begin{array}{c}\text { Carnobacterium } \\
\text { piscicola }\end{array}$ & $\begin{array}{c}\text { Carnobacterium } \\
\text { divergens }\end{array}$ & $\begin{array}{l}\text { Vagococcus } \\
\text { salmoninarum }\end{array}$ & $\begin{array}{l}\text { Lactococcus } \\
\text { piscium }\end{array}$ \\
\hline Growth in acetate agar & + & - & - & - & - \\
\hline Arginine dihydrolase & V & + & + & - & - \\
\hline \multicolumn{6}{|l|}{ Acid production from: } \\
\hline Mannitol & V & + & - & - & + \\
\hline Inulin & V & + & - & - & - \\
\hline Praduction of $\mathrm{H}_{2} \mathrm{~S}$ & - & - & - & + & - \\
\hline Hydrolysis of starch & V & - & - & + & + \\
\hline Major cellular fatty acids & cis-vaccenic & oleic & oleic & oleic & cis-vaccenic \\
\hline
\end{tabular}

Because lactic acid bacteria form a heterogeneous biochemical group of some importance to aquaculture, we have listed several tests in Table 3 that should be useful for the rapid differentiation of species that make up this biochemical group.

The bacterial isolate responsible for the present epizootic proved to be resistant to most of the chemotherapeutic agents commonly used in aquaculture such as oxytetracycline, the quinolones, the nitrofurans, and the potentiated sulfonamides. Chloramphenicol exhibited only an intermediate activity (Table 2). The drugresistant pattern of our isolate was consistent with the results obtained on the affected farm where a quinolone (oxolinic acid) proved ineffective and chloramphenicol proved moderately effective. In general, regardless of the source of isolation, all of the Lactobacillus-Carnobacterium strains seemed to be sensitive to erythromycin (Michel et al. 1986, Baya et al.
1991). Unfortunately, to date, this antibiotic has only been used for controlling bacterial kidney disease caused by Renibacterium salmoninarum (Evelyn et al. 1986, Elliott et al. 1989, Brown et al. 1990).

The negative results obtained in the virological analysis using different fish cell lines suggested that a concomitant viral infection was not involved in the epizootic.

\section{Serological and antigenic characteristics}

The results of agglutination assays indicated that the Carnobacterium piscicola PT-31 isolate was not serologically related to the reference strains ATCC 35586 and HB-426 (titers < 10). In addition, no cross-reactions were detected with the antisera raised against the Renibacterium salmoninarum or Corynebacterium aquaticum strains (Table 4).

Table 4. Slide agglutination and cross-agglutination titers of the Carnobacterium piscicola isolates

\begin{tabular}{|c|c|c|c|c|}
\hline \multirow[t]{3}{*}{ Antigen } & \multicolumn{4}{|c|}{ Source of rabbit antiserum: } \\
\hline & \multicolumn{2}{|c|}{ Carnobacterium piscicola } & \multirow{2}{*}{$\begin{array}{c}\text { Renibacterium } \\
\text { salmoninarum } \\
\text { ATCC } 33209\end{array}$} & \multirow{2}{*}{$\begin{array}{c}\text { Corynebacterium } \\
\text { aquaticum } \\
\text { RB 968BA }\end{array}$} \\
\hline & ATCC 35586 & HB- 426 & & \\
\hline \multicolumn{5}{|c|}{ Carnobacterium piscicola } \\
\hline PT-31 & $-(<10)$ & $-(<10)$ & $-(<10)$ & $-(<10)$ \\
\hline ATCC 35586 & $+(1280)^{a}$ & $-(<10)$ & $-(<10)$ & $-(<10)$ \\
\hline $\mathrm{HB}-426$ & $(+)(80)$ & $+(1280)$ & $-(<10)$ & $-(<10)$ \\
\hline $\mathrm{HB}-569 \mathrm{~L}$ & $-(<10)$ & $-(<10)$ & $-(<10)$ & $-(<10)$ \\
\hline $\mathrm{RB}-498$ & $-(<10)$ & $-(<10)$ & $-(<10)$ & $-(<10)$ \\
\hline \multicolumn{5}{|c|}{ Renibacterium salmoninarum } \\
\hline ATCC 33209 & $-(<10)$ & $-(<10)$ & $+(5120)$ & $-(<10)$ \\
\hline \multicolumn{5}{|c|}{ Corynebacterium aquaticum } \\
\hline RB 968BA & $-(<10)$ & $-(<10)$ & $-(<10)$ & $+(2048)$ \\
\hline
\end{tabular}




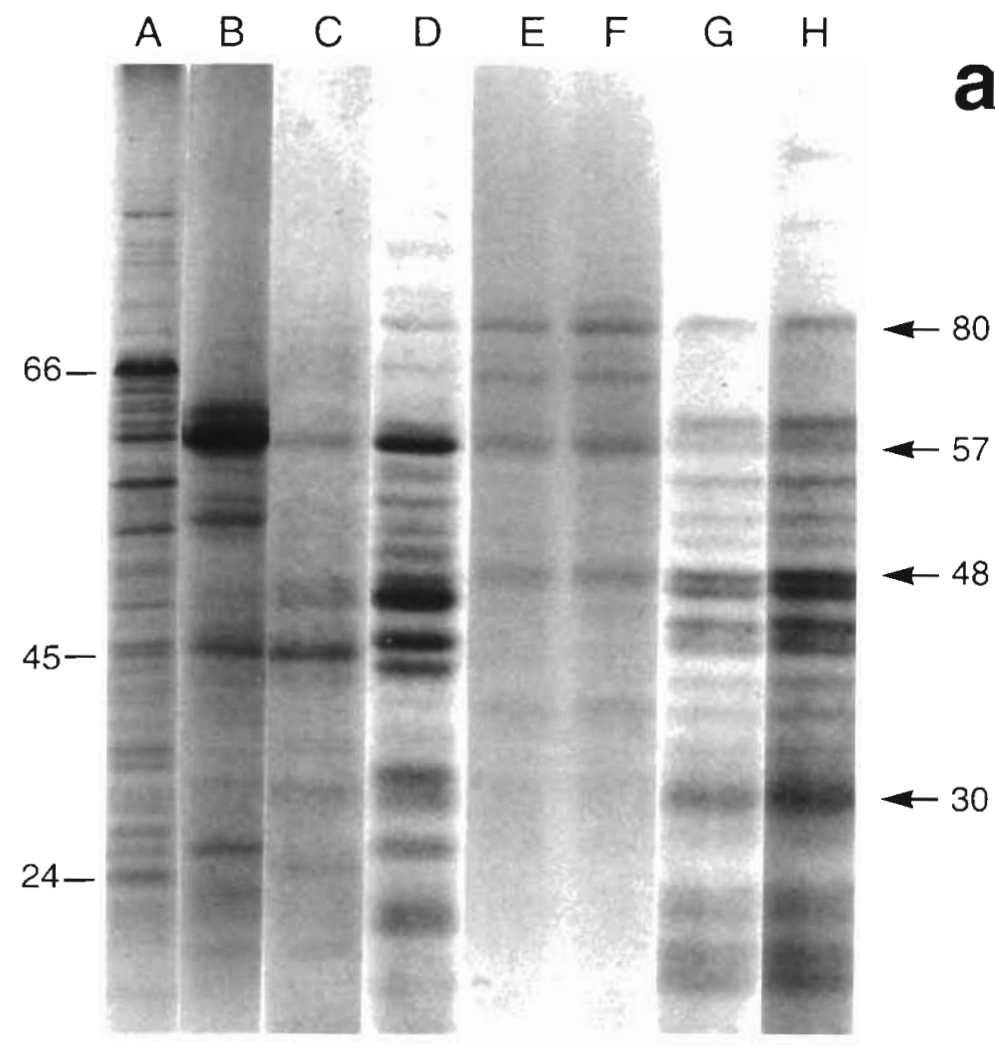

Fig. 2. SDS-PAGE of cell-surface proteins of Carnobacterium piscicola, Renibacterium salmoninarum, and Corynebacterium aquaticum strains (a), and the corresponding western blots using rabbit antisera raised against $C$. piscicola ATCC 33568 (b), and $R$. salmoninarum ATCC 33209 (c). Lanes: (A) C. aquaticum RB 968 BA; (B) R. salmoninarum ATCC $33209_{\text {; }}$ (C) C. piscicola RB-498; (D) C. piscicola HB-569L; (E \& F) C. piscicola PT-31 and PT-32 (isolates in the present outbreak); (G) C. piscicola $\mathrm{HB}-426$; (H) C. piscicola ATCC 35586. Numbers on the left indicate the molecular weight of protein standards in kDa. Arrows show cell surface proteins shared by most of the C. piscicola strains. Arrowheads indicate the major antigenic protein bands common to the isolates
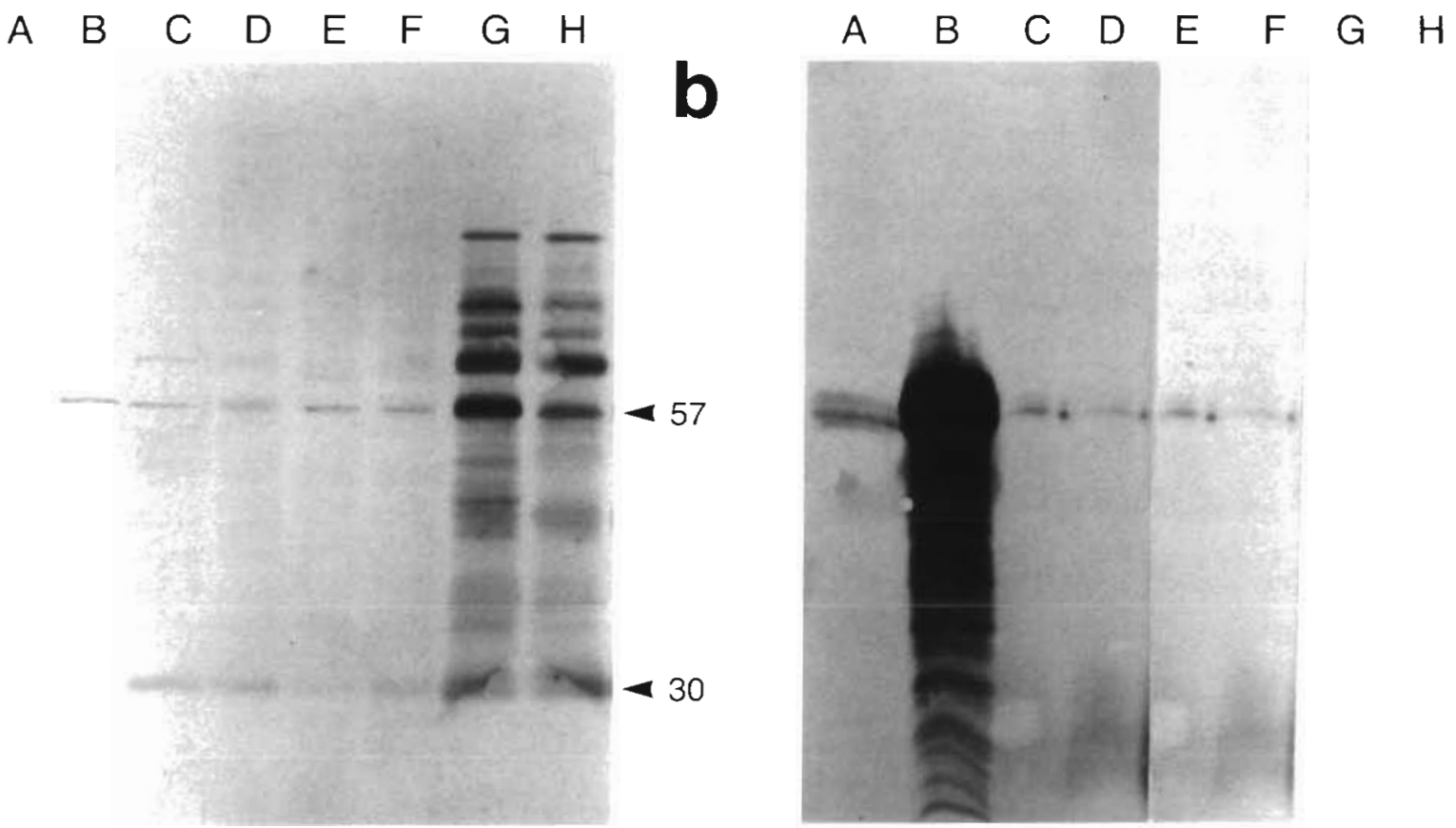

C

The analysis of surface proteins revealed that our isolate possessed a protein pattern different from those exhibited by the Carnobacterium piscicola reference strains, although some bands were shared in common by most straints (e.g. 80,57,48, 30 kDa) (Fig 2a). Only the ATCC 35586 and HB-426 strains showed an essentially identical profile which was supported by immunoblotting using the respective homologous antisera. In addition, these western blot assays indicated that all the $C$. piscicola isolates did share at least 
Table 5. Susceptibility of rainbow trout Oncorhynchus mykiss to live cells and extracellular products (ECP) of Carnobacterium piscicola. Qualitative appearance of reisolated bacteria by streaking organs directly onto BHIA plates: ++ , exuberant bacterial growth; + , moderate growth; -, no growth. $L D_{50}$ : number of viable cells or $\mu \mathrm{g} \mathrm{ECP}$ protein $\mathrm{g}^{-1}$ fish needed to kill $50 \%$ of the inoculated fish. Values in parenthesis show the mean CFU ${ }^{-1}$ kidney tissue. NA: not applicable

\begin{tabular}{|c|c|c|c|c|c|c|c|c|}
\hline \multirow[t]{3}{*}{ Strain } & \multicolumn{6}{|c|}{ - Live cells } & \multicolumn{2}{|c|}{$\longrightarrow \mathrm{ECP}-$} \\
\hline & \multirow[t]{2}{*}{$\mathrm{LD}_{50}$} & \multicolumn{4}{|c|}{ Reisolation from dead fish } & \multirow{2}{*}{$\begin{array}{l}\text { Recovery from } \\
\text { kidney of survivors }\end{array}$} & \multirow{2}{*}{$\begin{array}{l}\text { Lethal } \\
\text { effects }\end{array}$} & \multirow[t]{2}{*}{$\mathrm{LD}_{50}$} \\
\hline & & Kidney & Liver & Spleen & Brain & & & \\
\hline \multirow[t]{2}{*}{ PT-31 } & $<5.0 \times 10^{4}$ (i.p. injection) & $++\left(2.3 \times 10^{8}\right)$ & ++ & ++ & + & $+\left(5.0 \times 10^{3}\right)$ & + & 4.5 \\
\hline & $<6.0 \times 10^{4}$ (water-borne) & ++ & t+ & ++ & + & + & & \\
\hline ATCC & $2.6 \times 10^{6}$ (i.p. injection) & $++\left(8.0 \times 10^{7}\right)$ & + & + & - & $+\left(7.5 \times 10^{2}\right)$ & + & 10 \\
\hline 35586 & $>5.0 \times 10^{7}$ (water-borne) & NA & NA & NA & NA & - & & \\
\hline
\end{tabular}

2 major antigenic bands of about 30 and $57 \mathrm{kDa}$ (Fig. 2b). Interestingly, this immunoreactive $57 \mathrm{kDa}$ protein was also produced by the Renibacterium salmoninarum and Corynebacterium aquaticum reference strains. Similarly, using antiserum from $R$. salmoninarum ATCC 33209, all the C. piscicola strains exhibited the antigenic $57 \mathrm{kDa}$ band (Fig. 2c). These results support our preliminary findings (Bandín et al. 1993) and, therefore, allow us to reaffirm that any immunodiagnostic procedure relying on the specific detection of $R$. salmoninarum $57 \mathrm{kDa}$ antigen can suffer from false positive reactions with other Grampositive bacteria.

The negative results in the cross-agglutination assays among the isolates may be due to the possibility that the majority of common membrane proteins are not exposed to the antibodies or that they occur in such low amounts as to be unmeasurable in agglutination reactions, or to a combination of both effects.

All of these findings indicate that Carnobacterium piscicola is an antigenically heterogeneous species. This makes serological diagnosis of the disease difficult but this variability could be used in epidemiological studies to trace sources of infection.

\section{Pathobiological activities of live cells and extracellular products}

Virulence tests conducted by i.p. inoculation and water challenge indicated that our isolate PT-31 was highly pathogenic for rainbow trout, with a mean $L D_{50}$ value of $<5 \times 10^{4}$ cells by injection and $<6 \times 10^{4}$ by water challenge. Mortalities occurred within 3 to $7 \mathrm{~d}$ after challenge (Table 5). It is noteworthy that all of the moribund fish exhibited most of the external and internal clinical signs of the natural disease (i.e. pronounced exophthalmia, abdominal swelling with accumulation of ascitic fluid, and hemorrhages in the liver, intestine and musculature). In contrast, the reference strain Carnobacterium piscicola ATCC 35586 exhibited a low degree of virulence, being only pathogenic by i.p. injection $\left(\mathrm{LD}_{50}=2.6 \times 10^{6}\right.$ cells). Mortalities accurred more slowly (between Day 4 and Day 12) and the dead fish did not exhibit any apparent clinical signs. This finding is in agreement with our previous reports in which this ATCC strain was also tested for comparative purposes (Baya et al. 1991, Toranzo et al. 1993).

Although both of the challenge strains were recovered in pure culture from kidney, liver, and spleen of moribund trout, only in the case of our isolate PT-31 could the challenge organisms be reisolated from the brain. In addition, we recovered the inoculated bacterial strains from the kidney of survivor fish sacrificed $30 \mathrm{~d}$ after challenge, indicating that Carnobacterium piscicola can be harboured by the fish in a carrier state. Although in most of the challenge experiments conducted with Lactobacillus or Carnobacterium species, the microorganisms showed low virulence or failed to produce mortalities (Ross \& Toth 1974, Herman et al. 1985, Michel et al. 1986, Baya et al. 1991, Starliper et al. 1992), the carrier state could usually also be established in the fish populations using these microorganisms.

To evaluate the possible role of exotoxins in the virulence mechanisms of Carnobacterium piscicola PT-31 for rainbow trout, we determined the biological activities of its ECP in comparison with those shown by the reference ATCC strain. The total proteolytic activity of the ECP of each of the strains was very low (0.1 and $0.3 \mathrm{U} \mathrm{ml}^{-1}$, respectively) and caseinase, gelatinase, lipase, phospholipase and amylase activities were not detected. Moreover, cytotoxins or hemolysins were not detected in the ECP samples. This absence of enzymatic activities is similar to that reported for the ECP from Renibacterium salmoninarum (Bandín et al. 1989, Toranzo \& Barja 1993). However, unlike R. salmoninarum, C. piscicola produced exotoxins with lethal effects for fish; mortalities in treated fish occurred within 


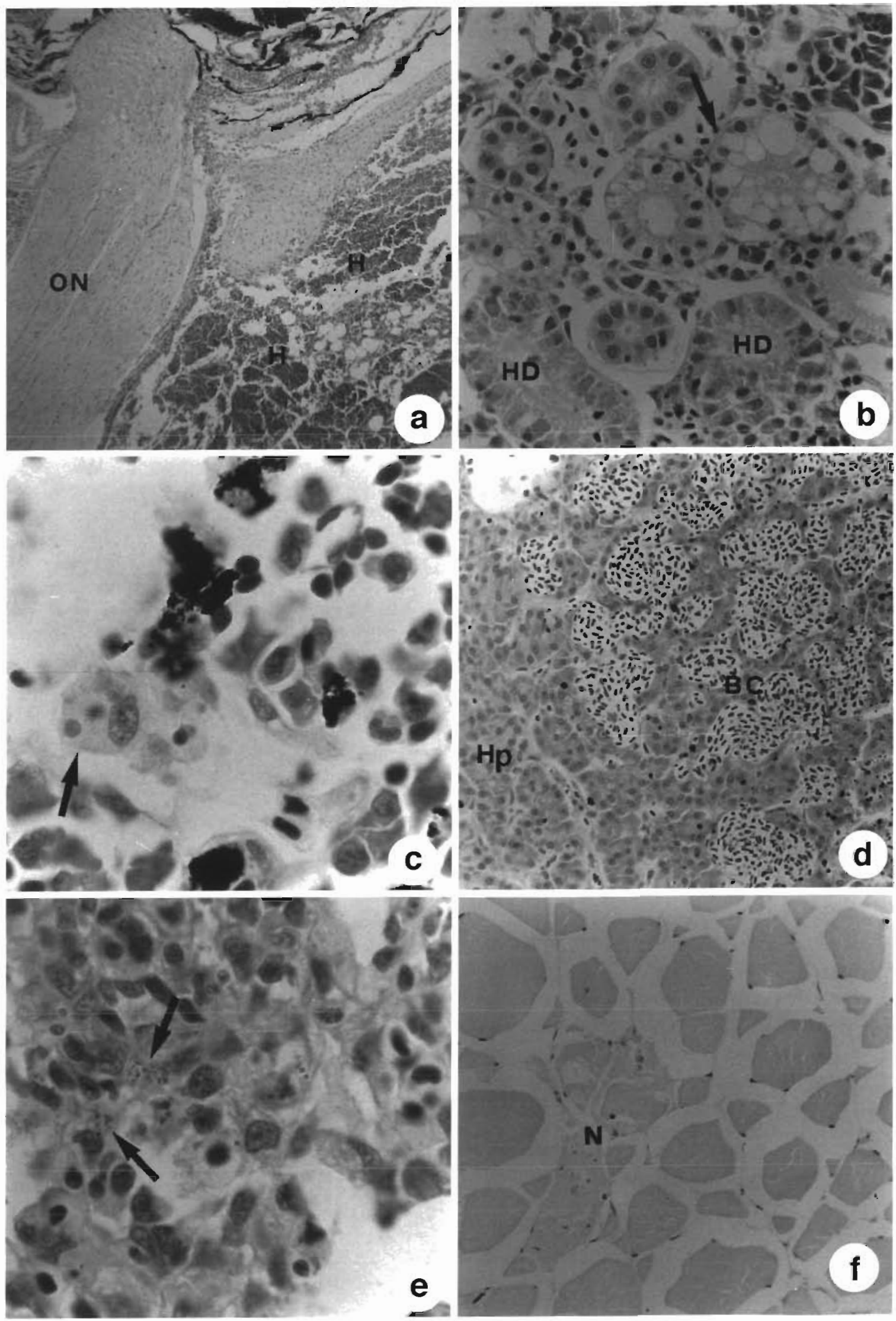


$24 \mathrm{~h}$ after i.p. or i.m. inoculation of the ECP. In contrast with the virulence assays with the live cells, the dead ECP-treated fish did not exhibit any significant clinical signs; only fish inoculated i.m. showed any adverse effects (an internal hemorrhagic zone around the injection site). The $L_{50}$ values of the ECP from PT-31 and ATCC strains were 4.5 and $10 \mu \mathrm{g}$ protein $\mathrm{g}^{-1}$ fish, respectively (Table 5), which were comparable to those reported for other fish pathogens (Toranzo \& Barja 1993).

Our in vitro tests did not help to account for the strong pathogenicity of our Carnobacterium piscicola isolate. However, we cannot rule out the possibility that there was in vivo production of different enzymes and/or toxins needed by the invading bacterium to proliferate in the specific tissues of fish. In addition, the rapidity with which the mortalities occurred following ECP injection could indicate the involvement of a neurotoxin.

\section{Histopathological examination}

Tissues of moribund rainbow trout taken from fish suffering the natural or experimental infection with Carnobacterium piscicola PT-31 were histologically examined to evaluate the changes produced in the different organs. This bacterial strain caused extensive and intensive pathological changes in the eyes, kidney, liver, spleen, pancreas, and muscle (Fig. 3). The eyes showed an intensive periocular hemorrhaging, and all of the adjacent orbital adipose tissue was markedly hemorrhagic and infiltrated with leucocytes (Fig. 3a). However, no obvious lesions were observed in the brain. In the kidney, a great number of renal tubules exhibited hyaline droplet degeneration, and the epithelium of some of these tubules was necrotic and vacuolated (Fig. 3b). In addition, many macrophages containing phagocytized erythrocytes were detected in the kidney (Fig. 3c). Mild localized hemorrhages were present in this organ. The liver showed extensive congestion in sinusoids, many blood lacunae being present (Fig. 3d). Hepatic cords were disorganized and in certain areas the hepatocytes were undergoing necrosis. The pulp of the spleen was edematous, hemorrhagic, and infiltrated with leucocytes (Fig. $3 e$ ).
The intestine showed necrosis of the mucous epithelium, and the acinar cells of the pancreas were also necrotic. However, no lesions were evident in the stomach and pyloric caeca. Red and white musculature underwent necrosis (Fig. 3f)

Although Gram-positive bacilli were observed in all of the organs examined, the highest bacterial numbers were found within the splenocytes and macrophages of the spleen (Fig. $3 e$ ) and in the necrotic pancreatic tissues.

These findings differ from those decribed in our recent paper dealing with the histophatological lesions produced by other Carnobacterium piscicola strains in rainbow trout and striped bass (Toranzo et al. 1993). These strains of $C$. piscicola caused only mild lesions in spleen and kidney. In addition, no damage to the eyes and musculature was observed. The present $C$. piscicola isolate PT-31 is thus clearly much more pathogenic and virulent than the other strains reported to date. It is noteworthy that the hemorrhages in the eyes displayed by our isolate were as severe as those seen in streptococcosis (Boomker et al. 1979, Miyazaki 1982, Baya et al. 1990) or in the recently described fish infection by Corynebacterium aquaticum (Baya et al. 1992)

\section{CONCLUDING REMARKS}

This report deals with the first case of a Carnobacterium piscicola infection in Spain. Heavy losses in cultured rainbow trout were experienced during the infection. At present, the source of the infection on the affected farm is unknown. The mortalities were most likely triggered by a sudden increase of water temperature because the fish had not experienced any other environmental or management stress. In contrast with previous reports, the present $C$. piscicola isolate exhibited a high degree of virulence in challenge experiments, a virulence that was supported by the strong histopathological changes that it caused in most of the fish organs examined. All of these findings warrant a reevaluation of the general assumption that the Gram-positive bacilli belonging to LactobacillusCarnobacterium species are opportunistic bacteria of low pathogenicity, and we hope that the information presented here serves to alert fish farmers to the exis-

Fig. 3. Oncorhynchus mykiss infected with Carnobacterium piscicola PT-31 strain. Histopathological lesions observed in the different organs of rainbow trout suffering the natural disease and the experimental i. p. challenge with live cells. (a) Intensive hemorrhage $(\mathrm{H})$ in the adipose tissue adjacent to the eye. ON: optical nerve. H\&E, 50x. (b) Hyaline droplet degeneration (HD) in the renal tubules of the kidney. Necrosis and vacuolation of the epithelium of some tubules (arrow). H\&E, 320x. (c) Red blood cells engulfed by macrophages in the kidney (arrow). H\&E, 1000x. (d) Extensive blood congestion (BC) in the sinusoids of the liver with blood lacunae being present. Normal aspect of the liver hepatocytes (Hp). H\&E, 300×. (e) Edematous pulp of the spleen showing bacteria within the splenocytes (arrows). H\&E, 1000×. (f) Necrosis (N) in the muscle. H\&E, 300x 
tence of strains possessing a range of virulence wider than that previously considered within these bacterial groups.

Because Carnobacterium piscicola strains are highly resistant to the majority of the drugs commonly employed in aquaculture, we urge that consideration be given to using erythromycin for controlling $C$. piscicola infections.

Acknowledgements. This investigation was supported in part by Grant MAR 91-1133-CO2-01 from the Comision Interministerial de Ciencia y Tecnología (CICYT) of Spain.

\section{LITERATURE CITED}

Amos, K. H. (ed.) (1985). Procedures for the detection and identification of certain fish pathogens, 3rd edn. Fish Health Section, American Fisheries Society, Corvallis, OR

Bandín, I., Santos, Y., Barja, J. L., Toranzo, A. E. (1993). Presence of a common antigen among Renibacterium salmoninarum, Corynebacterium aquaticum and Carnobacterium piscicola using the western blot technique. J. aquat. Anim. Hlth 5: 172-176

Bandín, I., Santos, Y., Bruno, D. W., Raynard, R. S., Toranzo, A. E., Barja, J. L. (1989). Lack of biological activities in the extracellular products (ECP) of Renibacterium salmoninarum. Can. J. Fish. Aquat. Sci. 48: 421-425

Baya, A. M., Lupiani, B., Bandín, J., Hatrick, F. M., Figueras, A., Carnahan, A., May, E. M., Toranzo, A. E. (1992). Phenotypic and pathobiological properties of Corynebacterium aquaticum isolated from diseased striped bass. Dis. aquat. Org. 14: 115-126

Baya, A. M., Lupiani, B., Hetrick, F. M., Roberson, B. S., Lukacovic, R., May, E. M., Poukish, C. (1990). Association of a Streptococcus sp. with mortalities in the Chesapeake Bay and its tributaries. J. Fish Dis. 13: 251-253

Baya, A. M., Toranzo, A. E., Lupiani, B., Li, T., Roberson, B. S., Hetrick, F. M. (1991). Biochemical and serological characterization of Carnobacterium spp. isolated from farmed and natural populations of striped bass and catfish. Appl. environ. Microbiol. 57: 3114-3120

Boomker, J., Imes, G. D., Camerson, C. M., Naude, T W., Schoonbee, H. J. (1979). Trout mortalities as a result of Streptococcus infection. Onderstepoort $J$ vet. Res. 46: $71-77$

Bradford, M. M. (1976). A rapid and sensitive method for the quantitation of microgram quantities of protein utilizing the principle of protein-dye binding. Analyt. Biochem. 72 : $248-254$

Brown, L. L., Albright, L. J., Evelyn, T P. T (1990). Control of vertical transmission of Renibacterium salmoninarum by injection of antibiotics into maturing female coho salmon Oncorhynchus kisutch. Dis. aquat. Org. 9: 127-131

Collins, M. D., Farrow, J. A. E., Phillips, B. A., Ferusu, S., Jones. D. (1987). Classification of Lactobacillus divergens, asporogenous, rod-shaped bacteria from poultry in a new genus, Carnobacterium Int. J. system. Bactenol. 37 : $310-316$

Cone, D. K. (1982). A Lactobacillus sp. from diseased female rainbow trout, Salmo gairdneri Richardson, in Newfoundland, Canada. J. Fish Dis. 5: 479-485

Elliot, D. G., Pascho, R. J., Bullock, G. L. (1989). Developments in the control on bacterial kidney disease of salmonid fishes. Dis. aquat. Org. 6: 201-215
Evelyn, T. P. T., Ketcheson, J. E, Prosperi-Porta, L. (1986). Use of erythromycin as a means of preventing vertical transmission of Renibacterium salmoninarum. Dis. aquat. Org. 2: $7-11$

Evelyn, T. P. T., McDermott, L. A. (1961). Bacteriological studies of fresh water fish. Can. J. Microbiol. 7: 375-382

Herman, R. L., McAllister, K., Bullock, G. L., Shotts, E. B. (1985). Postspawning mortality of rainbow trout (Salmo gairdneri) associated with Lactobacillus. J. Wildl. Dis. 21. $358-360$

Hiu, S. F., Holt, R. A., Sriranganathan, N., Seidler, R. J., Fryer, J. L. (1984). Lactobacillus piscicola, a new species from salmonid fish. Int. J. system. Bacteriol. 34: 393-400

Humphrey, J. D., Lancaster, C. E., Gudkovs, N., Copland, J.W. (1987). The disease status of Australian salmonids: bacteria and bacterial diseases. J. Fish Dis. 10:403-410

Kandler, O., Weiss, N. (1986). Genus Lactobacillus Beijerink 1901. In: Sneath, P. H. A., Mair, N. S., Sharpe, M. E., Holt, J. G. (eds.) Bergey's manual of systematic bacteriology. Williams \& Wilkins, Baltimore, p. 1209-1234

Knöchel, S. (1981). Microbiel fermentering af fisk v.h.j.a naturligt forekommende lactobaciller. Stud. brom thesis, Technical University, Lyngby

Kvasnikov, E. I., Kovalenko, N. K., Mateninskaya, L. G. (1977). Lactic acid bacteria of freshwater fish. Microbiology 46 : $619-624$

Laemmli, U. K. (1970), Cleavage of structural proteins during the assembly of the head of bacteriophage T4. Nature 227 : $680-685$

Liu, P. V. (1957). Survey of haemolysin production among species of Pseudomonas. J. Bacteriol. 74: 718-727

Michel, C., Faivre, B., Kerouault, B. (1986). Biochemical identification of Lactobacillus strains from France and Belgium. Dis. aquat. Org. 2: 27-30

Miyazaki, T (1982). Pathological study on streptococcicoses Histopathology of infected fishes. Fish Pathol. 17: 39-47

Montel, M. C., Talon, R., Fournaud, J., Champomie, M. C. (1991). A simplified key for identifying homofermentative Lactobacillus and Carnobacterium spp. from meat. J. appl. Bacteriol. 70: 469-472

Reed, L. J., Müench, H. (1938). A simple method of estimating fifty percent end points. Am. J. Hyg. 27: 493-497

Ross, A., Toth, R. J. (1974). Lactobacillus - a new fish pathogen? Prog. Fish Cult. 36: 191

Rucker, R. E., Earp, B. J., Ordal, E. J (1953). Infectious diseases of Pacific salmon. Trans. Am. Fish. Soc. 83: 297-312

Santos, Y., Bandín, I., Nuñez, S., Montero, M., Silva, A. Toranzo, A. E. (1992). Comparison of the extracellular biological activities of Vibrio angulllarum and Aeromonas hydrophila. Aquaculture 107: 259-270

Starliper, C. E., Shotts, E. B., Brown, J. (1992). Isolation of Carnobacterium piscicola and an unidentified gram-positive bacillus from sexually mature and post-spawning rainbow trout Oncorhynchus mykiss. Dis. aquat. Org. 13: $181-187$

Stoffels, G., Nes, I. F., Gudmundsdòttir, A. (1992). Isolation and properties of a bacteriocin-producing Carnobacterium piscicola isolated from fish. J. appl. Bacteriol. 73: 309-316

Toranzo, A. E., Barja, J. L. (1993). Virulence factors of bacteria pathogenic tor cold water fish. In: Faisal, M. Hetrick, F. M. (eds.) Annual review of fish diseases, Vol. 3. Pergamon Press, New York, p. 5-36

Toranzo, A. E., Barja, J. L., Colwell, R. R., Hetrick, F. M. Crosa, J. H. (1983a). Haemagglutinating, haemolytic and cytotoxic activities of Vibrio anguillarum and related vibrios isolated from striped bass on the Atlantic coast. FEMS Microbiol. Lett. 18: 157-162 
Toranzo, A. E., Barja, J. L., Potter, S. A., Colwell, R. R., Hetrick, F. M., Crosa, J. H. (1983b). Molecular factors associated with virulence of marine vibrios isolated from striped bass in Chesapeake Bay. Infect. Immun. 39: $1220-1227$

Toranzo, A. E., Baya, A. M., Roberson, B. S., Barja, J. L., Grimes, D. J., Hetrick, F. M. (1987). Specificity of the slide agglutination test for detecting bacterial fish pathogens. Aquaculture 61.81-97

Toranzo, A. E., Novoa, B., Baya, A. M., Hetrick, F. M., Barja, J. L., Figueras, A. (1993). Histopathological study in rainbow trout (Oncorhynchus mykiss, Walbaum) and striped bass (Morone saxatilis, Walbaum) experimentally infected with

Responsible Subject Editor: T. Evelyn, Nanaimo, B.C., Canada
Carnobacterium piscicola. J. Fish Dis. 16: 261-267

Towbin, H., Stachelin, T., Gordon, J. (1979). Electrophoretic transfer of proteins from polyacrylamide gels to nitrocellulose sheets: procedures amd some applications. Proc. natl Acad Sci. U.S.A. 76: 4350-4354

Wallbanks, S., Martínez-Murcia, A. J., Fryer, J. L., Phillips, B. A., Collins, M. D. (1990). 16S rRNA determination for members of the genus Carnobacterium and related lactic acid bacteria and description of Vagococcus salmoninarum sp. nov. Int. J. system. Bacteriol. 40: 224-230

Williams, A. M., Fryer, J. L., Collins, M. D. (1990). Lactococcus piscium sp. nov., a new Lactococcus species from salmonid fish. FEMS Microbiol. Lett. 68: 109-114

Manuscript first received: January 12, 1993

Revised version accepted: July 21, 1993 